\title{
Expression of type 1 fimbriae (SEF 21) of Salmonella enterica serotype Enteritidis in the early colonisation of the rat intestine
}

\author{
PATRICK J. NAUGHTON, GEORGE GRANT, SUSAN BARDOCZ, EMMA ALLEN-VERCOE*, MARTIN \\ J. WOODWARD* and ARPAD PUSZTAI
}

Rowett Research Institute, Greenburn Road, Bucksburn, Aberdeen AB21 9SB and *Department of Bacterial Diseases, Veterinary Laboratories Agency (Weybridge), Addlestone, Surrey KT15 $3 N B$

\begin{abstract}
The involvement of type 1 fimbriae in colonisation of the rat gastrointestinal tract in vivo was investigated with Salmonella enterica serotype Enteritidis LA5 and a mutant of LA5 denoted EAV3 unable to elaborate type 1 fimbriae (SEF 21). Rats were given a single dose of LA5 or EAV3 or a 1:1 mixture of both. LA5 was found in higher numbers in the stomach and small intestine than EAV3 at $6 \mathrm{~h}$ after infection with a single strain, but not after 6 days. LA5 did not out-compete EAV3 when the strains were administered together. Indeed, after 6 and 21 days, EAV3 was found in the distal small intestine and large intestine in far higher numbers than LA5. These findings suggest that SEF 21 have an important role(s) in the early stages of infection in vivo. However, SEF 21 expression may disadvantage the pathogen in the longer term as indicated by EAV3 out- competing LA5 in the gut at 21 days.
\end{abstract}

\section{Introduction}

An important step in infection by Salmonella spp. is their initial association with the surface of the gut epithelium. Salmonellae attach to a cell's surface through as yet unidentified molecules and subsequently initiate a signal tranduction cascade [1,2]. The role of fimbrial adhesins may be to mediate initial attachment to the host cell surface [3]. Fimbriae of Salmonella spp. were first described by Duguid et al. [4], and since then Salmonella enterica serotype Enteritidis has been shown to express three distinct fimbriae on its surface, including type 1 fimbriae (SEF 21) [5], SEF 14 [6] and SEF 17 [7], and has the potential to express plasmidencoded fimbriae [8] and long polar fimbriae [9].

The adhesion of $S$. Typhimurium to HEp-2 or HeLa cells is considered, at least in part, to be mediated by type 1 fimbriae [10]. Strains unable to express SEF 21 were less able to associate with and invade cultured epithelial cells [11] and fim deletion reduced adherence

Received 5 May 2000; revised version accepted 25 June 2000.

Corresponding author: Dr P.J. Naughton (e-mail: Patrick. Naughton@agrsci.dk). Present address: Department of Animal Nutrition and Physiology, Danish Institute of Agricultural Sciences, Research Centre Foulum, PO Box 50, DK-8830, Denmark. of $S$. Typhimurium to HeLa cells but not to HEp-2 cells [8]. Expression of mannose-sensitive haemagglutination by $S$. Typhimurium strains corresponded well with the observed levels of adhesion to HeLa cells [8]. Studies by Duguid et al. [12] noted that fimbriate $S$. Typhimurium dominated faecal cultures from orally infected mice. Recently, it was established in a rat model of salmonella infection that SEF 21 were expressed in vivo in the small intestine [13]. However, SEF 21 do not appear to play to a role in pathogenesis in a chick model [14].

McCormick et al. [15] showed that insertional inactivation of type 1 fimbriae in previously fimbriate Escherichia coli failed to diminish intestinal colonisation in individual animals. In contrast, inactivation of type 1 fimbriae has been found to abolish the ability of $E$. coli $\mathrm{K} 1$ to colonise the oropharynx but not the intestinal tract of the neonatal rat [16]. However, this may reflect the adhesin-receptor interaction, as the combining site of type 1 fimbrial lectin of $E$. coli has been shown to correspond to a trisaccharide of mannose [17]. FimH subunits studied to date are capable of mediating adhesion via trimannosyl residues, but only certain variants are capable of mediating high levels of adhesion via monomannosyl residues [18]. Salmonella type 1 fimbriae recognise a limited range of oligomannose motifs compared with E. coli. The reason for the lack of ascribed virulence function 
for SEF 21 may be that its individual contribution in host-pathogen interactions has thus far been difficult to define. In the present study, the fim $D$ gene in $S$. Enteritidis LA5 was insertionally inactivated to investigate the role of SEF 21 in a rat model in vivo.

\section{Materials and methods}

\section{Bacterial strains and growth}

Salmonella Enteritidis LA5 wild-type, LA5 ${ }^{\text {str }}$ LA5 $5^{\text {nal }}$ and $S$. Enteritidis LA5 EAV3 ( imD $^{-}$) were used in this study. These strains were grown for $48 \mathrm{~h}$ under static conditions in nutrient broth (CM1, Oxoid) to encourage maximal expression of SEF 21 [19] for studies in vivo and in vitro [20,21].

Strain LA5 is a virulent isolate that has been well characterised in culture studies in vitro [11] and in chick models [20]. It exhibits normal regulation of fimbrial expression amongst $S$. Enteritidis, expressing both SEF 21 and SEF 14 [22]. Strain EAV3 is a fimD mutant of LA5 constructed by insertion of a tetracycline resistance gene cassette into fimD [23]. Strain EAV3 has been characterised in various tissue culture and explant adherence models and in an in-vivo chick model [11,24]. Naladixic acid- and streptomycinresistant derivatives of the wild-type were constructed by plating overnight broth cultures on gradient plates separately containing naladixic acid and streptomycin. Well-defined colonies growing at relatively high concentrations of the antibiotics were picked from the antibiotic-containing plates. MICs were determined and LA5 ${ }^{\text {nal }}$ was sensitive at naladixic acid $32 \mathrm{mg} / \mathrm{L}$ and LA $5^{\text {str }}$ was sensitive at streptomycin $64 \mathrm{mg} / \mathrm{L}$. Strain LA5 and its derivatives were maintained on Dorset's egg slopes at $4^{\circ} \mathrm{C}$.

\section{Microbiology: bacterial counts and identification}

The tissues were weighed and homogenised in maximum recovery diluent (Oxoid; CM733). A 10-fold dilution series was prepared for the homogenates to a final dilution of $1 \times 10^{-7}$ and plated on XLD agar (Oxoid; CM469). Salmonellae were enumerated after incubation at $37^{\circ} \mathrm{C}$ for $16 \mathrm{~h}$ and the colonies were counted [25]. The presence of Salmonella colonies was confirmed with specific antisera (International Murex, Berkshire) and reactions in API 20E (bioMérieux, Basingstoke). The detection limit was $500 \mathrm{cfu} / \mathrm{g}$ wet weight or $/ \mathrm{ml}$. Spleen and liver samples were plated out by the pour-plate method [26]; the detection limit was $10 \mathrm{cfu} / \mathrm{g}$ wet weight. For infection studies, strain EAV3 was detected on XLD agar plates containing tetracycline $25 \mathrm{mg} / \mathrm{L}$, while $\mathrm{LA}^{\text {nal }}$ and $\mathrm{LA} 5^{\text {str }}$ were detected on plates containing naladixic acid or streptomycin, respectively.

\section{Salmonella growth curves}

To determine that the wild-type LA5 strain and its derivatives grew at the same rate, $S$. Enteritidis LA5, $\mathrm{LA}^{\text {str }}, \mathrm{LA}^{\text {nal }}$ and EAV3 were cultured for $16 \mathrm{~h}$ in nutrient broth at $37^{\circ} \mathrm{C}$ in a water bath under static conditions. Batch cultures $(10 \mathrm{ml})$ were then set up by inoculating at time 0 with $5 \mathrm{cfu}$ taken from a 16-h culture of each strain and incubated at $37^{\circ} \mathrm{C}$ for $12 \mathrm{~h}$ in a water bath. Every hour, one batch culture of each strain was sampled in duplicate. Samples $(1 \mathrm{ml})$ were serially diluted and then plated on to XLD agar or XLD agar with the appropriate antibiotic.

\section{Fimbrial expression}

Strains were grown statically for $48 \mathrm{~h}$ at $37^{\circ} \mathrm{C}$ in nutrient broth. Cells were centrifuged at $1300 \mathrm{~g}$ for 15 min. Cells were washed twice in phosphate-buffered saline (PBS: Oxoid; BR14a) $\mathrm{pH} 7.2$, and suspended in their original volume to give $c .1 \times 10^{8} \mathrm{cfu} / \mathrm{ml}$.

To detect SEF 21, mannose-sensitive haemagglutination assays (MSHA) were performed as described previously [19]. Briefly, horse erythrocytes were used as a $3 \%$ suspension in PBS, $\mathrm{pH}$ 7.2. A 50- $\mu$ l volume of erythrocyte suspension was mixed with equal volumes of bacterial culture and PBS on a ceramic tile, rocked for $4 \mathrm{~min}$ at room temperature $\left(20^{\circ} \mathrm{C}\right)$ and the presence of SEF 21 was indicated by haemagglutination. To confirm mannose sensitivity, PBS was replaced with Dmannose (Sigma) 3\% $\mathrm{w} / \mathrm{v}$ in PBS.

A SEFEX kit (VLA, Addlestone, Surrey) was used to detect SEF 14 expression. Briefly, equal volumes of bacterial culture and latex reagent were mixed on a test card and rocked for $4 \mathrm{~min}$ at room temperature. Agglutination indicated the presence of SEF 14 [27].

\section{Animal handling and experimental protocol}

The small animal unit of the Rowett Research Institute is licensed under the UK Animals (Scientific Procedures) Act 1986 and both the animal welfare unit of the institute and the appropriate government inspectorate regulate its operation. All management and experimental procedures conducted during this study were done in strict accordance with the requirements of the UK Animals (Scientific Procedures) Act 1986 by staff personally licensed under this act to perform such procedures.

Male Hooded Lister rats (19 days old) were housed individually in metabolism cages and fed a semisynthetic diet containing lactalbumin $100 \mathrm{~g} / \mathrm{kg}$ as the sole protein source [28]. Rats were fed ad libitum for 12 days. On reaching $80 \pm 1 \mathrm{~g}$ they were fed the above diet at $6 \mathrm{~g} / \mathrm{rat} /$ day for the duration of the experimental protocol. Water was available ad libitum. The rats were fasted for $16 \mathrm{~h}$ and given c. $1 \times 10^{8} \mathrm{cfu} / \mathrm{ml}$ of 
Salmonella by gavage. Post-mortem examinations were carried out as described previously [29,30] immediately following an overdose with halothane (Merial, Harlow) and exsanguination.

\section{Infection studies with EAV3 and LA5 ${ }^{\text {str }}$}

Fifteen rats were separated into three groups of five each. One group was given LA5 $5^{\text {str }}$, the second group was given EAV3 and the third group was given a combined inoculum of LA5 ${ }^{\text {str }}$ and EAV3. Post-mortem examinations were performed after $6 \mathrm{~h}$.

A further 15 rats were separated into three groups of five each. One group was given LA5 $5^{\text {str }}$, the second group EAV3 and the third group were given a combined inoculum of LA5 $5^{\text {str }}$ and EAV3. Rats given the single strains were killed after 6 days and those dosed with a combination of LA5 ${ }^{\text {str }}$ and EAV3 were killed after 3 days.

\section{Infection studies with EAV3 and LA5 $5^{\text {nal }}$}

Ten rats were given both $L A 5^{\text {nal }}$ and EAV3 in a combined inoculum by gavage. Rats were killed after 6 and 21 days.

\section{Statistical analysis}

The results were subjected to one-way analysis by the Minitab computer program (Minitab, State College, PA, USA) and multiple comparisons were done by the Tukey and Welch's test with the Instat statistical package (Graphpad Software, San Diego, CA, USA).
Table 1. Bacterial strains used in this study

\begin{tabular}{lll}
\hline Strain & Fimbriae expressed & Reference \\
\hline$S$. Enteritidis LA5 & SEF 21, 14 & 20 \\
$S$. Enteritidis LA5 $^{\text {st }}$ & SEF 21, 14 & This study \\
S. Enteritidis LA5 & SEF 21, 14 & This study \\
$S$. Enteritidis LA5 EAV3 & SEF 14 & 14 \\
\hline
\end{tabular}

\section{Results}

\section{Expression of SEF 21 and growth curves}

The phenotypic expression of fimbriae by $S$. Enteritidis LA5 and mutant derivatives is given in Table 1 . There was no evidence that isogenic mutation or the insertion of antibiotic resistance cassettes affected the growth kinetics (Fig. 1). Strain LA5 $5^{\text {str }}$ and LA5 ${ }^{\text {nal }}$ used in the in-vivo studies had a haemagglutination titre of 64 against horse erythrocytes and this haemagglutination was inhibited by mannose. Strain EAV3 did not exhibit mannose-sensitive haemagglutination. Colonies of EAV3 were randomly selected from samples collected from infected animals and were cultured for up to $48 \mathrm{~h}$ to test whether EAV3 reverted to wild-type phenotype. No SEF 21 expression was detected.

\section{Animal model experiments}

Salmonella numbers in the stomach of rats dosed with LA $5^{\text {str }}$ alone were much higher $(p<0.05)$ at $6 \mathrm{~h}$ than in animals given the SEF $21^{-}$mutant (EAV3) by itself (Fig. 2a). However, if LA5 $5^{\text {str }}$ was given in combination with EAV3, the amounts of LA $5^{\text {str }}$ in the stomach were greatly reduced and were similar in number to EAV3 (Fig. 2a, right). The levels of EAV3 in the stomach at $6 \mathrm{~h}$ were similar irrespective of whether the strain was given alone or in combination with $\mathrm{LA} 5^{\text {str }}$.

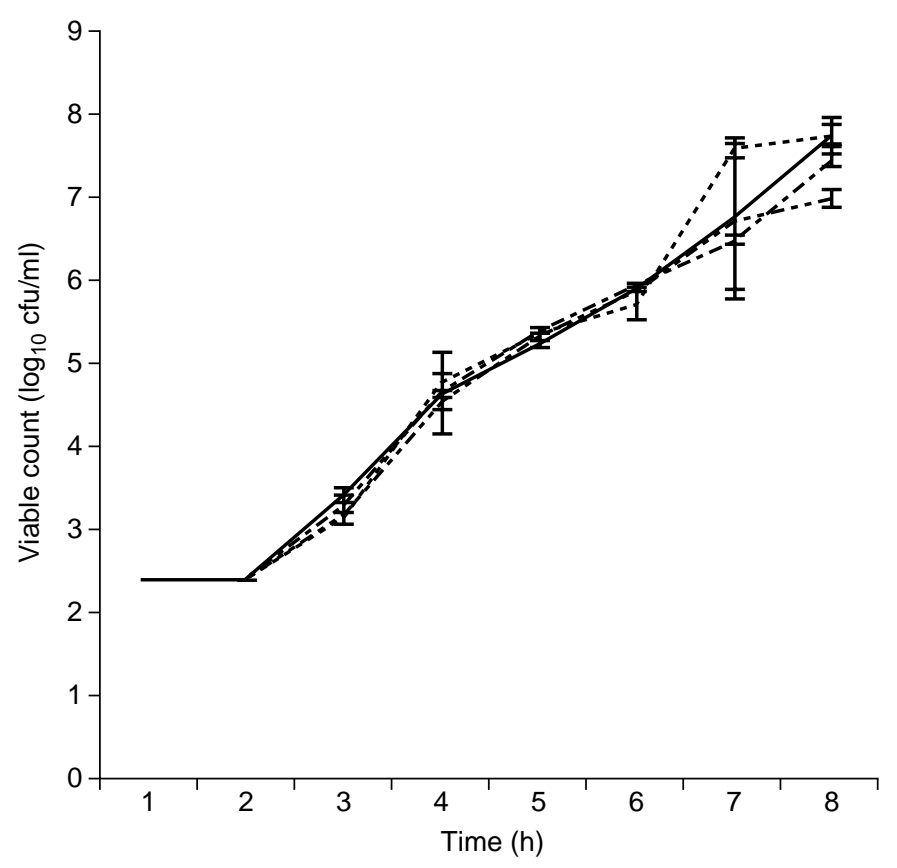

Fig. 1. Growth curve of $S$. Enteritidis LA5 (-) and its derivatives (--, LA5 EAV3; -.--, LA5 $5^{\text {str }}$; ---, LA5 $\left.5^{\text {nal }}\right)$. The strains were cultured in nutrient broth (error bars indicate $\mathrm{SD} ; \mathrm{n}=2$ ). 
(a)
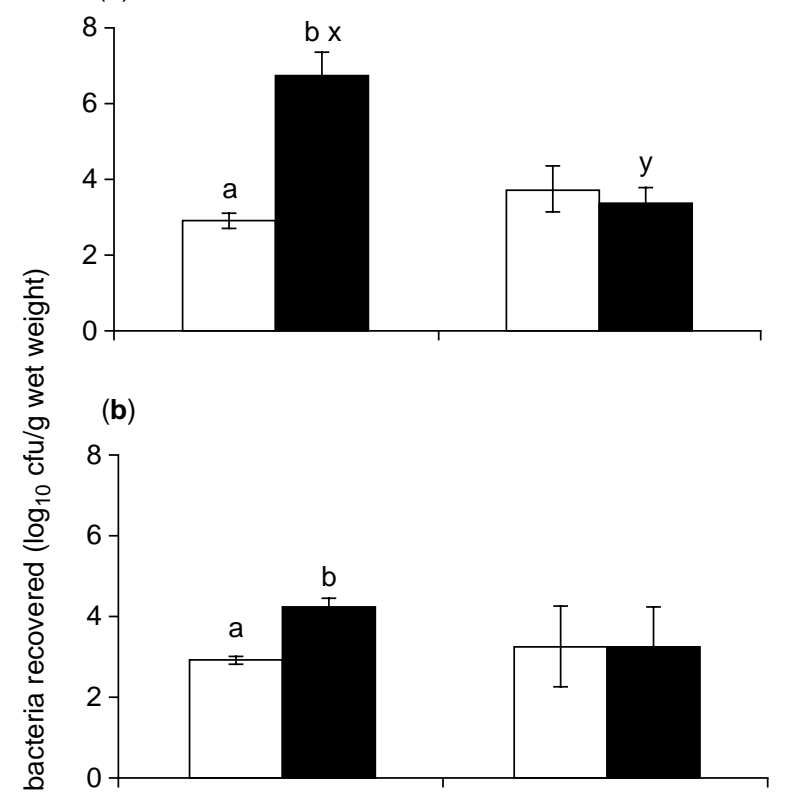

(c)

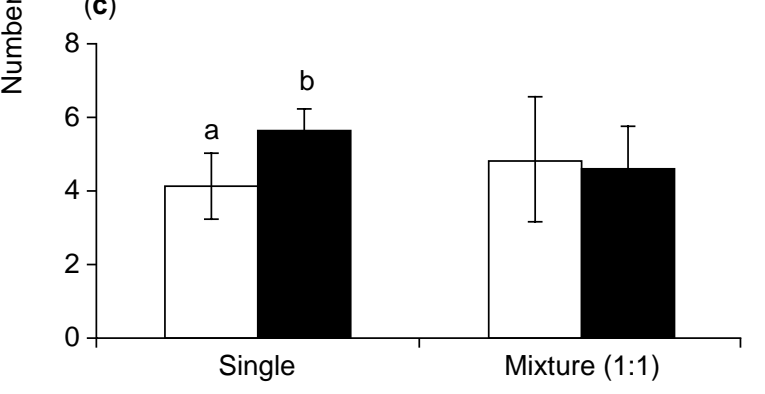

Fig. 2. Salmonellae ( $\square$, EAV3; a, LA5) recovered from tissue $6 \mathrm{~h}$ after inoculation: (a) stomach, (b) distal jejunum, (c) ileum. Three groups $(\mathrm{n}=5)$ were dosed orally with $10^{8} \mathrm{cfu}$. One group was dosed with a $1: 1$ mixture of two strains, LA5 $5^{\text {str }}(0.5 \mathrm{ml})$ and EAV3 $(0.5 \mathrm{ml})$. Two groups were dosed singly with either LA5 $5^{\text {str }}(1.0 \mathrm{ml})$ or EAV3 $(1.0 \mathrm{ml})$. Data are arithmetic means. Error bars indicate SD. Letters on top of bars $(a, b)$ represent significant differences between LA5 and EAV3 in single dose experiments. Letters $x$ and $y$ represent significant differences between dosing regimens $(\mathrm{p}<0.05)$.

At $6 \mathrm{~h}$, the numbers of LA5 $5^{\text {str }}$ in the small intestine of rats given only this strain were significantly higher $(p<0.05)$ than in animals given EAV3 alone (Fig. $2 b$ and $\mathrm{c}$ ). In contrast, there were no differences in the number of LA5 $5^{\text {str }}$ or EAV3 in the small intestine when the strains were given in combination to the rats (Fig. $2 b$ and $c$, right). There were no significant differences $(p<0.05)$ between LA5 $5^{\text {str }}$ and EAV3 numbers in the caecum and colon at $6 \mathrm{~h}$ (data not shown).

The numbers of salmonellae throughout the gastrointestinal tract of rats 6 days after they were given LA5 ${ }^{\text {str }}$ alone did not differ significantly from those found in rats given EAV3 alone. LA $5^{\text {str }}$ numbers $(\mathrm{cfu} / \mathrm{g})$ were: ileum, 3.9 (SD 0.3); caecum, 4.5 (SD 0.4); colon, 4.1 (SD 0.3). EAV3 numbers were: ileum, 4.4 (SD 0.4); caecum, 3.9 (SD 0.7); colon, 3.9 (SD 0.8). (a)

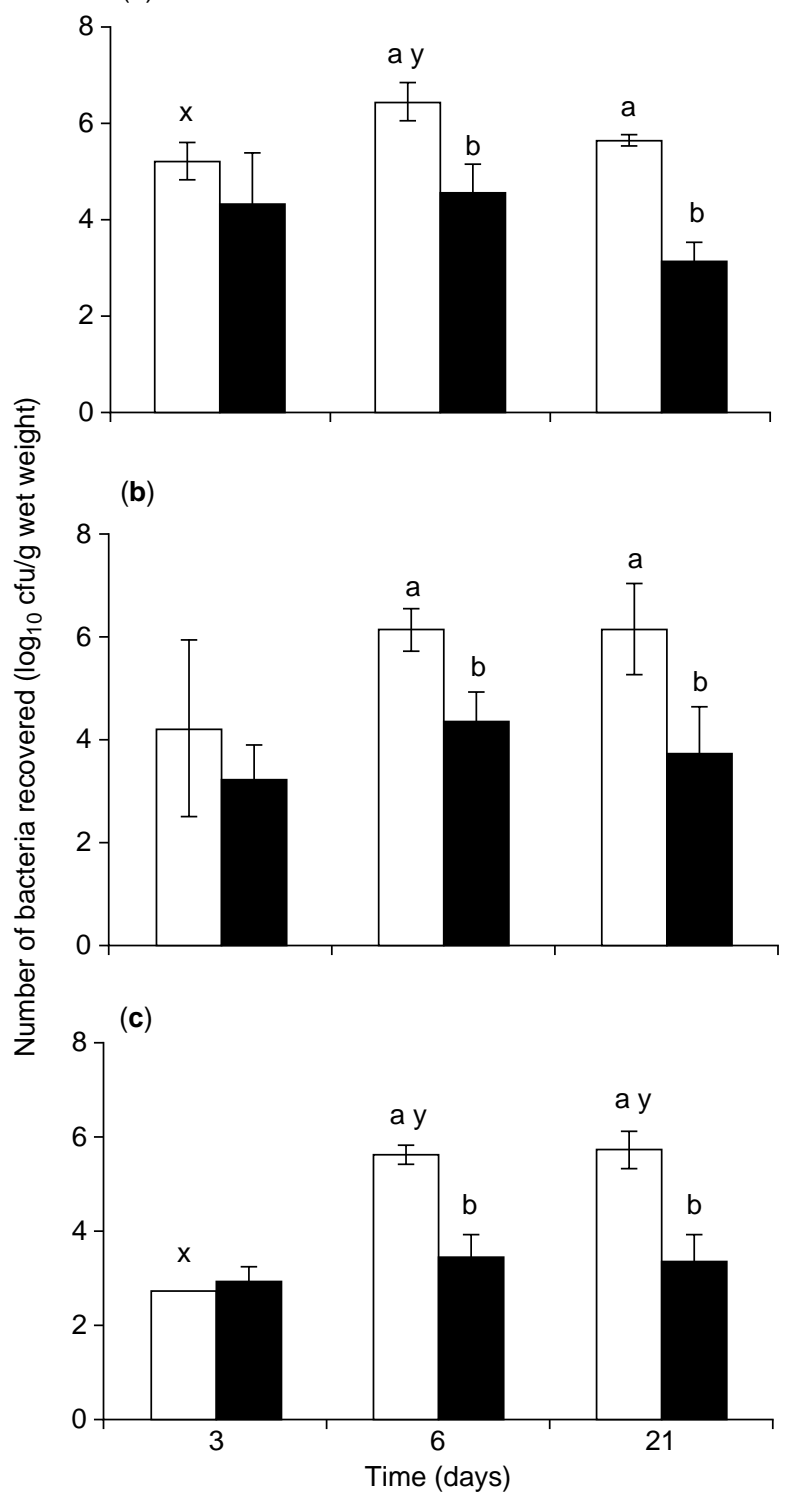

Fig. 3. Salmonellae ( $\square$, EAV3; $\mathbf{n}$, LA5) recovered from tissue 3, 6 and 21 days after inoculation: (a) ileum, (b) caecum, (c) colon. Three groups $(\mathrm{n}=5)$ were dosed orally with $10^{8} \mathrm{cfu}$. Each group was dosed with a 1:1 mixture of two strains, LA5 $5^{\text {nal }}(0.5 \mathrm{ml})$ and EAV3 $(0.5 \mathrm{ml})$. Data are arithmetic means. Error bars indicate SD. Letters on top of bars $(a, b)$ represent significant differences between EAV3 and LA5 in mixed dosing experiments. Letters $\mathrm{x}$ and $\mathrm{y}$ represent significant differences between time points $(\mathrm{p}<0.05)$.

LA5 ${ }^{\text {nal }}$ numbers in the ileum, caecum and colon were lower $(p<0.05)$ than those of EAV3 at 6 or 21 days after infection with a combined dose of the LA5 and EAV3 strains (Fig. 3). These differences were not evident at 3 days, nor were they apparent in other regions of the gut. Overall, numbers of the EAV3 strain in the intestine tended to increase $(p<0.05)$ with time, whereas those of the LA5 strain remained relatively stable (Fig. 3).

\section{Discussion}

The numbers of salmonellae found in the stomach and 
small intestine of rats $6 \mathrm{~h}$ after oral infection with a single strain were much higher when the bacterium was capable of expression of SEF 21. However, by 6 days no differences were evident. This suggests that SEF 21 may be an important virulence factor only during the early stages of infection and that, contrary to some indications [31], they convey no selective advantage in long-term persistence of infection. Struve and Krogfelt [32] have shown that the introduction of E. coli into the mouse urinary tract leads to markedly enhanced expression of type 1 fimbriae. If type 1 fimbriae have a transient role during the early stages of infection, this may explain why deletion of type 1 fimbriae from $E$. coli [16] or $S$. Enteritidis [14] failed to significantly alter the severity of infection in young rats or chicks. Studies with $E$. coli suggest that type 1 fimbriae can be down-regulated in long-term infection in the rat [33]. This would be consistent with the findings of the present study in which SEF 21 did not facilitate longterm persistence by Salmonella strains.

Few studies have examined the factors that influence type 1 expression in vivo; however, phase variation has been shown to occur during infection in animal models [34]. SEF 21 are not readily expressed in conditions of $\mathrm{pH}$ similar to those found in the rat stomach [35]. Thus, in the stomach it might have been expected that SEF 21 expression would have been low and that the LA5 and EAV3 strains would survive to similar extents in vivo. However, this was not the case. In rats given a single strain, higher numbers of LA5 than EAV3 were recovered from the stomach at $6 \mathrm{~h}$. This suggests that non-fimbriate strains may be cleared more rapidly from the stomach. Although the mechanisms involved are unknown, the ability of salmonellae to express SEF 21 appears to facilitate its survival in the stomach during the early stages of infection. Hendrickson et al. [36] found increased type 1 fimbrial expression following catabolic stress. Furthermore, Clegg et al. [37] showed that the fimA promoter region of $S$. Typhimurium was always oriented in the direction that might allow fimA transcription regardless of the fimbrial phase or environmental conditions in vitro. It is possible that the predisposition of the bacteria for expression of fimbriae ensures type 1 fimbriae are expressed in vivo even in the harsh conditions of the stomach.

However, possession of SEF 21 did not convey any selective benefit to LA5 when it was co-administered to rats with EAV3. This is in agreement with studies in mice where, in competitive experiments, E. coli F-18 phase locked 'on' for expression of type 1 fimbriae was recovered in lower numbers than the non-locked 'on' strain. [38]. In addition, May et al. [39] have shown that type 1 fimbrial expression can lead to diminution of the number of $E$. coli in peritoneal infections of rats and that a non-fimbriate insertional mutant can cause higher mortality in peritoneal infection. Similarly, Lockman and Curtiss [40] have shown that type 1 fimbriae of $S$. Typhimurium were not virulence factors in the mouse model and might in fact present a drawback to the pathogen. Much of the data on type 1 fimbriae of $S$. Typhimurium in mice $[12,41]$ and of $E$. coli in rats [42], suggests a role in dissemination rather than colonisation of intestinal sites. Indeed, in the present study, long-term expression of SEF 21 appeared to be disadvantageous. Thus, at 6 and 21 days, EAV3 persisted in the gastrointestinal tract in much higher numbers than LA5. In mice, Aslanzadeh and Paulissen [43] showed that both type 1 and type 3 fimbriae of $S$. Enteritidis contributed to virulence in mice. In chickens, Thiagarajan et al. [44] showed a role for fimbrial proteins in caecal colonisation by $S$. Enteritidis. In contrast, Rajashekara et al. [45] did not show any contribution by SEF 21 to the infection of chickens by $S$. Enteritidis. Similarly, other studies have shown that flagella and not fimbriae are important in the caecal colonisation of chickens $[14,24,46]$ by $S$. Enteritidis. Hence, colonisation of the gut by salmonellae is highly dependent on the host species and in particular cases is likely to involve the integrated action of a number of fimbriae and virulence factors. Whilst failure to express SEF 21 appears to disadvantage the mutant strain to a limited extent in the short-term, it may be insufficient to allow a SEF 21-expressing strain to out-compete a mutant that is capable of expressing other virulence factors with the exception of SEF 21.

Type 1 fimbriate $S$. Typhimurium appear to be cleared from the blood more rapidly than non-fimbriate organisms; they seem to be trapped selectively by the endothelial and Kupffer cells of the liver [47]. Vazquez-Torres et al. [48] have shown direct evidence that systemic spread of salmonellae depends on CD18expressing cells, strongly supporting the hypothesis that these bacteria can be carried within macrophages. Furthermore, fimbriate strains may be more susceptible to non-opsonised phagocytosis [49], i.e., salmonellae expressing fimbrial adhesins may bind to sugars on phagoctyic cells, resulting in metabolic activation of the phagocytes. This may mean that in the present study the fimbriate strain was preferentially removed from the gastrointestinal tract, allowing the mutant strain to become predominant in the long term. These studies indicate that SEF 21 may play a more active role in salmonella pathogenesis than previously thought. Further studies are needed to define this role.

We acknowledge the support of the Scottish Office Agriculture Environment and Fisheries Department. The generation of the afimbriate mutant of $S$. Enteritidis was funded jointly by the Ministry of Agriculture Fisheries and Foods and by the Department of Health (UK). We are grateful to Jeanette Robertson for her kind assistance and to Chris Thorns for helpful discussions.

\section{References}

1. Bliska JB, Falkow S. Bacterial resistance to complement killing mediated by the Ail protein of Yersinia enterocolitica. Proc Natl Acad Sci USA 1992; 89: 3561-3565. 
2. Falkow S, Isberg RR, Portnoy DA. The interaction of bacteria with mammalian cells. Annu Rev Cell Biol 1992; 8: 333-363.

3. van der Velden AWM, Bäumler AJ, Tsolis RM, Heffron F. Multiple fimbrial adhesins are required for full virulence of Salmonella typhimurium in mice. Infect Immun 1998; 66: 2803-2808.

4. Duguid JP, Anderson ES, Campbell I. Fimbriae and adhesive properties in Salmonellae. J Pathol Bacteriol 1966; 92 $107-138$.

5. Müller KH, Collingson SK, Trust TJ, Kay WW. Type 1 fimbriae of Salmonella enteritidis. J Bacteriol 1991; 173: 4765-4772.

6. Thorns CJ, Sojka MG, Chasey D. Detection of a novel fimbrial structure on the surface of Salmonella enteritidis by using a monoclonal antibody. J Clin Microbiol 1990; 28 2409-2414

7. Collinson KS, Doig PC, Doran JL, Cloutheir S, Trust TJ, Kay WW. Thin, aggregative fimbriae mediate binding of Salmonella enteritidis to fibronectin. J Bacteriol 1993; 175: 12-18.

8. Bäumler AJ, Tsolis RM, Heffron F. Contribution of fimbrial operons to attachment to and invasion of epithelial cell lines by Salmonella typhimurium. Infect Immun 1996; 64: $1862-1865$.

9. Bäumler AJ, Heffron F. Identification and sequence analysis of lpfABCDE, a putative fimbrial operon of Salmonella typhimurium. J Bacteriol 1995; 177: 2087-2097.

10. Tavendale A, Jardine CKH, Old DC, Duguid JP. Haemagglutinins and adhesion of Salmonella typhimurium to HEp2 and HeLa cells. J Med Microbiol 1983; 16: 371-380.

11. Dibb-Fuller MP, Allen-Vercoe E, Thorns CJ, Woodward MJ. Fimbriae- and flagella-mediated association with and invasion of cultured epithelial cells by Salmonella enteritidis. Microbiology 1999; 145: 1023-1031.

12. Duguid JP, Darekar MR, Wheater DWF. Fimbriae and infectivity in Salmonella typhimurium. $J$ Med Microbiol 1976; 9: 459-473.

13. Ewen SWB, Naughton PJ, Grant G et al. Salmonella enterica var Typhimurium and Salmonella enterica var Enteritidis express type 1 fimbriae in the rat in vivo. FEMS Immunol Med Microbiol 1997; 18: 185-192.

14. Allen-Vercoe E, Sayers AR, Woodward MJ. Virulence of Salmonella enterica serotype Enteritidis aflagellate and afimbriate mutants in a day-old chick model. Epidemiol Infect 1999; 122: 395-402.

15. McCormick BA, Franklin DP, Laux DC, Cohen PS. Type 1 pili are not necessary for colonization of the streptomycin-treated mouse large intestine by type 1-piliated Escherichia coli $\mathrm{F}-18$ and $E$. coli $\mathrm{K} 12$. Infect Immun 1989; 57: 3022-3029.

16. Bloch CA, Orndorff PE. Impaired colonization by the full invasiveness of Escherichia coli $\mathrm{K} 1$ bearing a site-directed mutation in the type 1 pilin gene. Infect Immun 1990; 58: 275-278.

17. Firon N, Ofek I, Sharon N. Carbohydrate specificity of the surface lectins of Escherichia coli, Klebsiella pneumoniae, and Salmonella typhimurium. Carbohydr Res 1983; 120: 235-249.

18. Sokurenko EV, Chesnokova V, Doyle RJ, Hasty DL. Diversity of the Escherichia coli type 1 fimbrial lectin. J Biol Chem 1997; 272: 17880-17886.

19. Sojka MG, Dibb-Fuller M, Thorns CJ. Characterisation of monoclonal antibodies specific to SEF 21 fimbriae of Salmonella enteritidis and their reactivity with other Salmonellae and Enterobacteria. Vet Microbiol 1996; 48: 207-221.

20. Cooper GL, Venables LM, Woodward MJ, Hormaeche CE. Invasiveness and persistence of Salmonella enteritidis, Salmonella typhimurium, and a genetically defined $S$. enteritidis aroA strain in young chickens. Infect Immun 1994; 62 4739-4746

21. Thorns CJ, Bell MM, Sojka MG, Nicholas RA. Development and application of enzyme-linked immunosorbent assay for specific detection of Salmonella enteritidis infections in chickens based on antibodies to SEF14 fimbrial antigen. $J$ Clin Microbiol 1996; 34: 792-797.

22. Dibb-Fuller M, Allen-Vercoe E, Woodward MJ, Thorns CJ Expression of SEF17 fimbriae by Salmonella enteritidis. Lett Appl Microbiol 1997; 25: 447-452.

23. Allen-Vercoe E, Dibb-Fuller M, Thorns CJ, Woodward MJ.
SEF17 fimbriae are essential for the convoluted colonial morphology of Salmonella enteritidis. FEMS Microbiol Lett 1997; 153: 33-42.

24. Allen-Vercoe E, Woodward MJ. The role of flagella, but not fimbriae, in the adherence of Salmonella enterica serotype Enteritidis to chick gut explant. J Med Microbiol 1999; 48: $771-780$.

25. Miles AA, Misra SS. The estimation of the bactericidal power of the blood. J Hyg 1938; 38: 732-749.

26. Collins CH, Lyne PM, Grange GM. Collins and Lyne's microbiological methods, 6th edn. London, Butterworths. 1989: 89.

27. Thorns CJ, McLaren IM, Sojka MG. The use of latex particle agglutination to specifically detect Salmonella enteritidis. Int $J$ Food Microbiol 1994; 21: 47-53.

28. Grant G, Dorward PM, Buchan WC, Amour JC, Pusztai A. Consumption of diets containing raw soya beans (Glycine max), kidney beans (Phaseolus vulgaris), cowpeas (Vigna unguiculata) or lupin seeds (Lupininus angustifolius) by rats for up to 700 days: effects on body composition and organ weights. Br J Nutr 1995; 73: 17-29.

29. Naughton PJ, Grant G, Spencer RJ, Bardocz S, Pusztai A. A rat model of infection by Salmonella typhimurium or Salm. enteritidis. J Appl Bacteriol 1996; 81: 651-656.

30. Naughton PJ, Grant G, Bardocz S, Pusztai A. Modulation of Salmonella infection by the lectins of Canavalia ensiformis (Con A) and Galanthus nivalis (GNA) in a rat model in vivo. J Appl Microbiol 2000; 88: 720-727.

31. Connell H, Agace W, Klemm P, Schembri M, Mårild S, Svanborg C. Type I fimbrial expression enhances Escherichia coli virulence for the urinary tract. Proc Natl Acad Sci USA 1996; 93: 9827-9832.

32. Struve C, Krogfelt KA. In vivo detection of Escherichia coli type 1 fimbrial expression and phase variation during experimental urinary tract infection. Microbiology 1999; 145: 2683-2690.

33. Hérias MV, Midtvedt T, Hanson LA, Wold AE. Role of Escherichia coli $\mathrm{P}$ fimbriae in intestinal colonization in gnotobiotic rats. Infect Immun 1995; 63: 4781-4789.

34. Lim JK, Gunther NW, Zhao H, Johnson DE, Keay SK, Mobley HLT. In vivo phase variation of Escherichia coli type 1 fimbrial genes in women with urinary tract infection. Infect Immun 1998; 66: 3303-3310.

35. Walker SL, Sojka M, Dibb-Fuller M, Woodward MJ. Effect of $\mathrm{pH}$, temperature and surface contact on the elaboration of fimbriae and flagella by Salmonella serotype Enteritidis. $J$ Med Microbiol 1999; 48: 253-261.

36. Hendrickson BA, Guo J, Laughlin R, Chen Y, Alverdy JC. Increased type 1 fimbrial expression among commensal Escherichia coli isolates in the murine cecum following catabolic stress. Infect Immun 1999; 67: 745-753.

37. Clegg S, Hancox LS, Yeh K-S. Salmonella typhimurium fimbrial phase variation and FimA expression. J Bacteriol 1996; 178: 542-545.

38. McCormick BA, Klemm P, Krogfelt KA et al. Escherichia coli F-18 phase locked 'on' for expression of type 1 fimbriae is a poor colonizer of the streptomycin-treated mouse large intestine. Microb Pathog 1993; 14: 33-43.

39. May AK, Bloch CA, Sawyer RG, Spengler MD, Pruett TL. Enhanced virulence of Escherichia coli bearing a site-targeted mutation in the major structural subunit of type 1 fimbriae. Infect Immun 1993; 61: 1667-1673.

40. Lockman HA, Curtiss R. Virulence of non-type 1-fimbriated and nonfimbriated nonflagellated Salmonella typhimurium mutants in murine typhoid fever. Infect Immun 1992; 60: 491-496.

41. Tanaka Y, Katsube Y, Mutoh T, Imaizumi K. Fimbriae of Salmonella typhimurium and their role in mouse intestinal colonization of the organism. Nippon Juigaku Zasshi 1981; 43: 51-62.

42. Bloch CA, Stocker BAD, Orndorff PE. A key role for type 1 pili in enterobacterial communicability. Mol Microbiol 1992; 6: 697-701.

43. Aslanzadeh J, Paulissen LJ. Adherence and pathogenesis of Salmonella enteritidis in mice. Microbiol Immunol 1990; 34: 885-893.

44. Thiagarajan D, Thacker HL, Saeed AM. Experimental infection of laying hens with Salmonella enteritidis strains that express different types of fimbriae. Poult Sci 1996; 75: $1365-1372$. 
45. Rajashekara G, Munir S, Alexeyev MF, Halvorson DA, Wells CL, Nagaraja KV. Pathogenic role of SEF14, SEF17, and SEF21 fimbriae in Salmonella enterica serovar Enteritidis infection of chickens. Appl Environ Microbiol 2000; 66: 1759-1763.

46. Allen-Vercoe E, Woodward MJ. Colonisation of the chicken caecum by afimbriate and aflagellate derivatives of Salmonella enterica serotype Enteritidis. Vet Microbiol 1999; 29: $265-275$.
47. Leunk RD, Moon RJ. Association of type 1 pili with the ability of livers to clear Salmonella typhimurium. Infect Immun 1982; 36: $1168-1174$.

48. Vazquez-Torres A, Jones-Carson $\mathrm{J}$, Bäumler $\mathrm{AJ}$ et al. Extraintestinal dissemination of Salmonella by CD18-expressing phagocytes. Nature 1999; 401: 804-808.

49. Ofek I, Goldhar J, Keisari Y, Sharon N. Nonopsonic phagocytosis of microorganisms. Annu Rev Microbiol 1995; 49: 239-276. 